\title{
The Boomerang Theology of Andrew Marvell
}

\section{NIGEL SMITH}

Résumé : La poésie lyrique d'Andrew Marvell a suscité quelques discussions bien connues de la poétique protestante, puritaine et contre-réformatrice. Toutefois la religion joue un autre rôle, presqu'entièrement inexploré, dans sa poésie. On a remarqué jusqu'à quel point ses æuvres en prose des années 1670, dans lesquelles il exprime ses opinions sur la tolérance religieuse, la liberté civile et l'absolutisme, incorporent des vers et des expressions remaniés de sa poésie, parmi d'autres références poétiques. Cet article considère la poésie de Marvell, autant en soi qu'en son remaniement, comme le chantier où a été forgée la largeur d'esprit manifestée dans sa prose.

Thirty years ago, the last time a large body of Marvell editions were published, the poet and politician's public life and professed belief presented a number of seemingly unsolvable difficulties that were at least helpful in explaining the ambiguities and ironies for which his most famous poems were celebrated. ${ }^{1}$ A Parliamentarian and Puritan; a friend of Milton, but someone who apparently expressed sympathy for King Charles I, and so, perhaps, a covert royalist. A friend of the nonconformists, during the Restoration, and a stout defender of liberty of conscience, but despite his attack on the bishops, someone who was prepared to defend them in certain circumstances. A vehement spokesman against popery, and its concomitant, arbitrary government, but someone prepared occasionally to defend Catholics.

We have come a long way in thirty years. What was once "loyalty," shorthand for a man who appeared to change his views with the times, but who, it was then contended, was really a moderate and always in favor of a strong executive, is now understood as the resourcefulness of a sophisticated 
mind, adopting a range of identities in response to rapidly changing circumstances: fellow traveler with exiled royalists, would-be republican poet, country house resident tutor and man of letters, Protectoral household poet, public voice of the Protectorate, civil servant, opposition M.P. in the Cavalier Parliament, conspiratorial poet/pamphleteer, scourge of the Restoration church, civil champion of the Dissenters, proto-Whig satirist and ideologue of toleration. ${ }^{2}$ Through all these identities, we are more likely to see him today as the "consistent opponent of arbitrary power and champion of man's rational freedom." 3 This is not to say that problems of interpretation do not remain. For instance, we still have to explain properly his late marriage, his relationship with the Hull business community, and the matter of his apparent poverty - all matters that further archival research should illuminate. To say nothing of the problems that his intricate writings continue to present.

The purpose of this essay is to discuss the relationship between Marvell's religious beliefs (inseparable to a large extent from his political views) and the literary qualities of his writing, both poetry and prose. Marvell's verse has recently been characterized as a combination of the highly disciplined (regular couplet rhymes, highly formed, regular stanzas) and the relatively liberal: frequent deviation from regular stress patterns, but never so much as to endanger the metrical shape of the whole. The use of the verse letter as a means of attacking astrology in the Latin poem on Joseph Maniban thus resists views that deny the exercise of personal responsibility. This is in contrast to harder taskmasters, like Milton in his epics, or, to come closer in time to the present, Robert Lowell, who make irregularity thematically functional. ${ }^{4}$ Marvell deals in containment, rather than constriction. Thus, his prosody may be said to embody the dilemmas and ambiguities that characterize his visions of political and personal liberty: the limits of free will or individual agency, and the force or frustration of determining external forces; the apparently pleasant exploitation of dire circumstances; the flight from what would generally be regarded as pleasant sociability or genuine commitment into refined isolation.

These paradoxes might be situated within the large and vital debate in early modern England concerning the relationship between verse and its true uses and Reformation worship. The struggle for a single prayer book in the reformed Church of England was necessarily concerned with the uses of poetry in worship: what are the liturgy and the metrical Psalms but vernacular sacred poetry? ${ }^{5}$ At the heart of this debate was the widely but variously understood relationship between form and power, word or letter and spirit, the structure of material objects (be they church fabric or words), on the one hand, inspiration or immediacy, on the other. Too much form and the result 
was dead worship, without the presence of the lively soul, and the mire in which, according to Protestants, Roman Catholic worship was lost. Too much power of the spirit and all order would be devoured by the vagaries or violence of enthusiasm. ${ }^{6}$

Somewhere in all of this sits Andrew Marvell's verse: closely involved in the post-Reformation debates concerning religious poetry and usually Protestant, sometimes even Puritan, in character. In a few instances the poet still confesses a knowledge of Catholicism that may have been the result of a brief conversion in youth, or the Royalism and high Anglicanism that he encountered during the 1630s and 1640s, both at home (largely Cambridge and London) and abroad. But the Reformation and Puritan traces are unavoidable. Marvell's pastorals and dialogues are notoriously strenuous. In Clorinda and Damon the arguments of the female temptress (itself a reversal of tradition) are effortlessly suppressed by Damon's pious urge to sing God's praises in a hymn, rather than to indulge in sexual pleasure. Bermudas takes the elegant psalm forms and light epic readily associated with the Caroline court and Puritanizes them in order to praise a prominent Puritan's appointment to the Protectorate's Bermudas committee. It may also have used a popular ballad as the basis for a song version, or for implied musical presence, the questioning tone and parenthesis (see 11. 8, 35) that have been seen to undermine the poem's confidence notwithstanding. ${ }^{7}$ To it must be added the classically Puritan sentiments of the Latin elegy for Jane Oxenbridge (wife, and a preaching wife at that, to the man for whom Bermudas was probably written), the two Latin elegies for the sons of the nonconformist-sympathizing M.P. Sir John Trott, and the excellent epitaph for Frances Jones - a highly-pointed defense of (by 1672) old-fashioned Puritan morals, disarmingly delivered in the voice of John Donne. The "Two Songs" that Marvell wrote for the wedding of Cromwell's youngest daughter Mary represent a further refinement of Milton's already Puritan pastoral, the ultimately violent religious politics of the context of the wedding notwithstanding. 8 "A Dialogue, Between the Resolved Soul, and Created Pleasure" has been connected with Paradise Lost and Paradise Regained, and uses courtly sensuousness as the temptation that the soul must overcome. It seems likely that the poem was indeed written after 1667, when Milton's epic was first published, and a copy was confiscated just two months after Marvell's death in 1678 in the lodgings of a suspected insurrectionist soldier. It was thus understood to be a genuinely militant Puritan poem, although its intricate design, rarefied reference to the Judgment of Paris, and stoical echoes of Seneca make it a very refined example. We can imagine without too much difficulty Marvell's verse at the court of Oliver Cromwell, but in the hands of nonconformists about to take up arms, new doors of awareness 
for the uses of poetry are opened for us. ${ }^{9}$ Another poem known to have been collected in manuscript by a Puritan (none other than the influential Baptist Hebrew scholar Hanserd Knollys) was "A Dialogue between the Soul and Body," a poem to which we will return.

"On a Drop of Dew," "Ros" and "Eyes and Tears" all genuflect in the direction of the tear topos in Roman Catholic poetry, although each in ways that pull back from genuine and partisan religious commitment. Perhaps the most striking example is in "Eyes and Tears," where stanza eight, dedicated to the Magdalene, dilutes the devotional theme in its allusiveness and its isolated position in the poem. The feature is not unlike those noticed in Marvell's elegies for royalist soldiers, where, despite apparent similarities with verse of this kind, Marvell pursues relative disengagement. ${ }^{10}$ "The Coronet" and "A Dialogue between the Soul and Body" contain emblematic and generic traces of other Counter-Reformation poems, but traces that had been firmly assimilated by Protestant poets. In the former, Marvell replaces Herbert's optimistic tone with doubt, as if to pull the reader back to the murky choices of faith facing young poets like Marvell. Thus, on the one hand, the poem supports readings that are Protestant, Calvinist and Puritan, and, on the other, implicitly offers a critique of the Puritan denial of human invention. "The Nymph Complaining for the Death of Her Fawn" begins with an invitation to consider the poem as a royalist Anglican allegory (the wanton troopers who shoot the fawn are likely to be Parliamentarian soldiers), and this is confirmed for the informed by the impeccably Royalist major source for the poem: Fanshawe's translation of Guarini's Il Pastor Fido. But the poem empties itself of these concerns as it proceeds, and as the nymph's inner life is developed. We have to put the poem against a background of other royalist works to see how its closing iconography might be regicidal or Anglican, but even this is dubious.

It is no little problem of interpretation that one of Marvell's most speculative poems, "The Garden," relies for its verbal architecture on at least three texts by Jesuits: one Englishman living abroad, one Pole, and, if we admit the source, a Spaniard. ${ }^{11}$ And yet "The Garden" is one of Marvell's most libertine poems. The "religion" that does seem to run through many of the poems is, in fact, that of the libertine. Not the sexual libertinism and concomitant materialism of Rochester - although Marvell would come to know those views and the milieu in which they flourished well enough but the speculative and poetic free-thinking typical of so much European baroque poetry, be it written by gentlemen or clergy, that enabled the fusion of Neostoicism, epicureanism, Neoplatonism, and fausse naïveté, any of these philosophical concerns plausibly tied up with religious themes. If any extra proof were needed that Marvell made a tour of Europe, and read widely 
in European vernacular literature, this would be it. Several of the continental volumes that provided him with source poems are difficult to find in British libraries today. "To his Coy Mistress" gathers the force of its carpe diem argument by amassing erotic poetic clichés, coupled with Epicurean and Lucretian touches, to make orgasm and death meet at a moment of explosive appeal, where the clichés in the poem are transformed into a strikingly original moment. In the verbal texture of the poem, this means a reworking of that most solemn of sacred texts, the Order for the Burial of the Dead in The Book of Common Prayer, and, even more blasphemously, the wording of the Collect for Easter Day. But equally, it might be said that the references to death also undermine the epicurean note, "annihilating" both death and pleasure in a claim for an erotic outrunning of nature that is only ever another death, and an imagined echoing voice in a worm-infested burial chamber. Fun all the same.

Marvell's employer, Thomas, Lord Fairfax, was an admirer of libertine verse, and understood it to be a means of reflecting upon God's works in creation, continuous with the nature mysticism of Hermes Trismegistus. In a poem of praise to his employer, Marvell makes "Upon Appleton House" reflect precisely Fairfax's interests, and since Fairfax and his wife were Presbyterians, the poem offers a staunch Protestant history of the Fairfax family. On the one hand, the valuable literary inheritance of late medieval Yorkshire is preserved in the poetic landscape of the poem, while the anti-Reformation elements in Fairfax history are either presented critically or ignored. ${ }^{12}$ The often noted playfulness of the poem - from reversed perspectives (fish in trees, cows in water), through the tweaking of Davenant's epic pretensions, to the country maid Thestylis speaking out of the poem to the poet (who thus doubles as God) - is consistent with libertine poetics. Before we reach the poem's climax - the praise of Mary Fairfax as the future of the Fairfax line - we meet the speculatively playful narrator in an uncharacteristically solitary moment, and it is to this moment that I wish to return later.

All of this illustrates the observation with which this essay began: Marvell capitalizes on the energies of contrary forces as both a theme and an embodiment, at every level of poetic construction. They are usually figured as one kind of doubleness or another: a reversal, an instance of reflexivity, or a "self-inwoven device." They are self-conceived more than once by Marvell as an "echoing song," and very recently they have even been labelled a "boomerang" method. ${ }^{13}$ Hence the centrality in all explanations of Marvell's procedures of the description of the Commonwealth from The First Anniversary: 
144 / Renaissance and Reformation / Renaissance et Réforme

The Common-wealth does through their Centers all

Draw the Circumf'rence of the publique Wall;

The crossest Spirits here do take their part,

Fast'ning the Contignation which they thwart;

And they, whose Nature leads them to divide,

Uphold, this one, and that the other Side;

But the most Equal still sustein the Height,

And they as Pillars keep the Work upright;

While the resistance of opposed Minds,

The Fabrick as with Arches stronger binds,

Which on the Basis of a Senate free,

Knit by the Roofs Protecting weight agree. (11. 87-98)

These internally conflicting forces might as well be applied to the church as the state. We do not know Marvell's views about religion in this period with precision, but to read backward from the Restoration, he cannot have been too far from having personal sympathy with Cromwell's attempt to build a broad-based national church, and he treats sympathetically two of its architects, John Owen and Richard Baxter, albeit two whose views diverged from each other in some important respects. The famous lines from The First Anniversary also have a source in Milton's Areopagitica, where Milton himself lifts phrases from the description of the construction of the Temple in 1 Kings 5-6. In doing this, Milton was already inverting a text that was usually used to suggest the need for utter conformity. Marvell develops Milton's emphasis upon "many schisms and many dissections made in the quarry and in the timber, ere the house of God can be built"14 into "the resistance of opposed Minds, / The Fabrick as with Arches stronger binds" (11. 95-96), Fifth Monarchist resistance to the Protectorate notwithstanding. Somewhere in here are the broad Protestant church commended by Andrew Marvell senior, and the open church, possibly integrating and certainly not persecuting nonconformists, that Andrew junior hoped to see in the Restoration but never did. In The First Anniversary, that vision is millennial:

Hence oft I think, if in some happy Hour

High Grace should meet in one with highest Pow'r, And then a seasonable People still

Should bend to his, as he to Heavens will, What we might hope, what wonderful Effect

From such a wish'd Conjuncture might reflect.

Sure, the mysterious Work, where none withstand, Would forthwith finish under such a Hand:

Fore-shortned Time its useless Course would stay, And soon precipitate the latest Day. (11. 131-40) 
Between Oliver and the Restoration came the Protectorate of Richard Cromwell, a further time when hopes for a broad national Puritan church, as celebrated by Richard Baxter, were extenuated. Marvell's first and very brief stint as M.P. for Hull was during this period; in most respects, he supported Richard and was uncharacteristically open enough to voice his aversion to the republicans at this time.

The combination of evident commitment to a religious polity in these state poems with the subtly questioning powers of poetic representation results in a reconstruction of several central phenomena and themes in church history. As Paul Mathole has argued, Marvell's representation of martyrs (in the Flecknoe poem, in Captain Douglas of the Restoration satires, and in James Mitchell in Scaevola Scoto-Brittannus), questions the relationship between the suffering of the martyr and the rightness of his cause. In each case, "it can be couched in a language of sacrifice that resists a portrayal of martyrdom." 15 And, as I have argued elsewhere, the rich cultural associations that Marvell builds out of these portrayals of "martyrdom," ranging from church history and Christology to Ovid, Roman sculpture and beyond, make us see the way in which martyrdom is produced across cultural and religious divides (quite unlike the way in which most contemporaries would have seen things), and produced by tyrannous behavior. ${ }^{16}$ The poetry has rewritten church history under the aegis of liberty of conscience, and the aesthetic of tolerant consideration that it demands. In this context, the conceits in "A Dialogue between the Soul and Body" of the body as the prison of the soul and the soul as the torturer of the body become a horrifying rebus of what religious persecution means, not least in the image of the soul "impaling" the body, which suggests either torture or execution by forcing a stake through the anus and out of the mouth. ${ }^{17}$

If Marvell's poetry may be characterized as the combination of containment and liberty, to the benefit of a quintessentially existential and necessarily ironic sense of personal liberty, the claim has also been made that his prose is all about liberty and nothing else: "In polemics, and in matters of belief, the far-from-passive Marvell always leaves space for human freedom and responsibility. ... he has a consistent predisposition towards individual freedom. . . . Marvell is constant . . . in his opposition to religious superstructures, to what he sees as the unbiblical institution of creeds, bishops and ceremonies." 18 These are fair judgments, but they are based on manifest content, rather than, as is the case with the poetry, on an understanding of the interaction between prosody and theme. What happens if we look for this relationship in the prose?

Nearly all of the prose begins in the form of an animadversion of one kind or another, which is to say an attack on the writings of an opponent by 
the successive quoting of sections from those writings, followed by a refutation. The Rehearsal Transpros'd, Parts 1 and 2 (1672-73) and Mr. Smirke: or the Divine in Mode (Mr. Smirke, 1676) involve respective ad hominem attacks on Samuel Parker and Francis Turner. Remarks upon a Late Disingenuous Discourse (1678) is similarly defensive. Only the A Short Historical Essay Council touching General Councils, attached to the end of Mr. Smirke (but also circulating separately), and An Account of the Growth of Popery and Arbitrary Government (1677), escape these conditions, and the latter is so clearly in the voice of an ideal speaker that it uncannily resembles a Swift tract, like The Conduct of the Allies. ${ }^{19}$ And in this respect, we do not have to look very far for a figure of containment. In Mr. Smirke, Marvell's speaker likens himself repeatedly to Popilius drawing a line in the sand around King Antiochus, telling him not to step out of it until he had promised not to attack the Romans. ${ }^{20}$ The comparison is all the more startling for its use of political, imperial and military concerns to articulate religious matters, and since Popilius was known for his temper, this is an interesting piece of self-reflection by Marvell, who, in the previous decade, had struck another M.P. (of superior social rank) and had pistol-whipped a sleigh driver in Germany. ${ }^{21}$

Prose polemic should be characterized by its argument, and while there is no shortage of this in Marvell's prose satires, we are being invited at the same time to consider the "wit" that resides in these pages, too. In part, this is because of the tradition in ecclesiological debate of humorous abuse that stemmed back to the Marprelate tracts of the 1580s and before. In Dryden's view, Marprelate was the Marvell of the late sixteenth century. ${ }^{22}$ But, as we shall see, Marvell is doing something quite distinctive. It is wit that delivers the double-sided qualities in the poetry as well as the prose, but Marvell makes both belong to the same category. The opening sections of both The Rehearsal Transpros'd and Mr. Smirke make the point by having lines of verse punctuate successive paragraphs. The containment provided by rhyme also functions here as a critical device: a rhyming sentence in Turner is used by Marvell to criticize purported laziness of faith in the use of creeds or a simple confession of faith without internal conviction. Harping on a string and scanning on one's fingers are instances of poetic club-footedness being used to demonstrate incompetence in the realm of controversy. 23

There can be no objection to the proper qualities of the Marvellian sentence. It is well balanced, periodic where necessary, and duly proportioned with a cadence that carries gravity and conviction. It also exemplifies the conventions of humanist punctuation in its use of the colon, and, being unafraid to begin with conjunctions, reflects ancient prose: 


\begin{abstract}
But however, to write a Book of that virulence, and at such a season, was very improper: even in the Holy time of Lent, when, whether upon the Sacred account, it behoved him rather to have subjugated and mortified the swelling of his passions; or whether upon the Political reason, he might well have forborn his young Wit, as but Pigg'd or Calv'd, in order to the growth of the yearly Summer Provisions. ${ }^{24}$
\end{abstract}

There is little doubt that we are in the presence of someone who knows the workings of the church inside out, someone indeed who was the son of a hardworking clergyman, who had grown up in a former monastic building, and who almost certainly had entertained thoughts for some time of ordination. No one could accuse Marvell of not being a true son of Cicero, the reassertion of rhetorical magnificence being one of the values admired by the restored bishops after 1660. That sense of "it could have been me" runs through Marvell's prose, just as Marvell's satire on Flecknoe reflects on his own encounter with Catholicism and the concomitant implications for Marvell's poetic career. ${ }^{25}$ Indeed, in The Rehearsal Transpros'd, there are phrases that imitate those in the Flecknoe satire, as if Marvell were imagining his dispute with Parker as the witty theological and literary conversation in Rome that is recorded in the poem. ${ }^{26}$

But there are other qualities here that subvert the expectation of mere argument, even mere animadversion. Both clergymen under attack are imagined as satirical characters in plays: Parker as a simulacrum of Dryden, as the poet had been ridiculed in the Duke of Buckingham's The Rehearsal (where he has been represented as the character of Mr. Bayes), and Turner as a fusion of Dorimant and Sir Fopling Flutter in Etherege's The Man of Mode. Mr. Bayes (i.e., Samuel Parker) has risen above himself because he has acted so many kings before. The language of Buckingham's play is quoted alongside Parker's writing in order to generate the irony of the satire, and this is singularly apt, Marvell claims, because so many plays had satirically (mis)represented the nonconformists. It is possibly a dramatic riposte that Marvell offers so many theologically astute echoes of Shakespeare in The Rehearsal Transpros'd, as if to instruct the likes of Dryden and Aphra Behn in how to write a proper play. Stage Puritans, pre- and post-1660, were usually presented as mentally deranged. Being vulnerable to unguarded passions is a trait of the characters we see mocked, gently or less so, earlier on in the poetry, such as Flecknoe, and Marvell's intimate knowledge of raunchy Restoration London, which the plays both represent and embody, will soon further startle the reader. But what makes us sit up is the picture of ecclesiastical hectoring as the thuggish tactics of a desperate and unsubtle playwright. The vestry has become a tiring room, the mode of discourse, the new one of dramatic criticism, fused with coffee-house-cum- 
newsbook observation. The tone is startling, the dramatic tension (and indeed irony) exquisite:

The Vestry and the Tiring-room were both exhausted, and 'tis hard to say whether there went more attendants towards the Composing of Himself, or of his Pamphlet. Being thus drest up, at last forth he comes in Print. No Poet, either the First or the Third day, could be more concern'd; and his little Party, like men hired for the purpose, had posted themselves at every corner, to feign a more numerous applause: but clap'd out of time, and distub'd the while Company. ${ }^{27}$

The next sentence, which is the first after the preface, breeches decorum with its description of Turner "bolting" (to pass judgment before enquiry) as if he were a horse. But the substantive issue at hand is in fact a matter of deciding where Herbert Croft, whom Turner attacks, stands with his prose. Turner's accusation is that he is an enthusiast and virtually a fanatic, even if he does not realize this. Marvell simply asserts that Croft's sentences are truly pious, and nothing more at this point in his preface than a recapitulation of Luke 2:14, the song of the angels at the birth of Christ. The speaker says that if this is enthusiasm, he is happy to be of that party, and we the reader must see Turner's claim to be "Spiritual, Divine, and Canonical" as hollow.

Marvell considered, and thought the reading public agreed, that $M r$. Smirke was inferior to The Rehearsal Transpros' $d$. Nonetheless, what I have just described in Mr. Smirke is true of The Rehearsal Transpros'd: the seizure of his opponent's argument in such a way as to redefine him into "an epitome of all that his writings seem to oppose." 28 Parker, like Turner, is turned into exactly that which he attacks, and which he claims he is not: an enthusiast (Parker had resorted to a most unpleasant caricature of a nonconformist, but he was a staunch Presbyterian before 1660). Ironic reversal has triumphed.

It is Marvell's gift as an animadverter that he gives the impression of being able to voice his opponent's hidden intentions. This is extremely well done, and achieved by using quotations from Turner, who in turn is shown to be conducting an indecent anatomy on Croft. The effect in Marvell's text is indeed proto-Swiftian, since Turner is revealed to be a cruel and violent persecutor, and mad, a Yahoo avant la lettre: "Such like also is his talking, that this is stripping the Church to the skin, nay skin and all, and skin for skin: so wretchedly does he hunt over hedg and ditch for an University Quibble.... I have heard a Mad-man having got a word by the end ramble after the same manner." 29 The key words are developed beyond Croft and Turner's texts, so that the references to skin come from the tempting of Satan in Job 2:4, while Turner's mocking obsession with the skin references in Croft reveals him to be concerned only with his own skin (Curare Cuticu- 
lum). The completeness of the satire in such a short space is very satisfying, when the reader has puzzled it out, and the only possible objection can be that it requires a focus so narrow (and hence a total discourse of a very great length) that the reader might justifiably feel frustration at the burden placed upon him. That sense of completion is aided not merely by the portrayal of interaction between Turner and Croft but also by the fact that the speaker sees himself as involved in the same activity as the animadverter: they have both learned to scan verses at grammar school. ${ }^{30}$ This is an aspect that repeats the treatment of Parker in The Rehearsal Transpros' $d .{ }^{31}$ Later on, and with the help of Ovid, Turner is likened to the crow that was once white but turned black by Apollo because of his lying. ${ }^{32}$ The introduction of the "we" again is like a conceptual rhyme, just as the extensive invocation of "skin" is a figure of repetition. Marvell's point in doing this is revealed a few pages later, when he directly compares Turner as Mr. Smirke to Flutter, picking up on Dryden's epilogue couplet to Etherege's play, where it is suggested that Flutter represents the follies of the entire audience: "From each he meet he culls whate'er he can; / Legion's his name, a people in a man." 33 Amidst some further play on Turner's doubtful ability to be considered a representative of anyone (he is now presented as a corrupt M.P. who agrees, or "undertakes," to vote in a certain way, and where he is so turbulent, he is like the Parliament in dispute between the upper and lower houses, as happened in the spring and summer of 1675), Marvell's point is clear: Turner is no representative of any of us, however much he may claim to be so.

And yet there is more: the text moves into allegory, and a double-sided one at that, of Turner as a spiritual knight. ${ }^{34}$ Turner's armour (since he is likened in one sense to a Parliament) is three Acts: the Act of Uniformity of 1662, the Printing and Licensing Act of May 1662, and the Act against Seditious Conventicles of 1670 (enforcing an earlier act of 1664). Against this the Church (of England) should be armed with the shield of faith (from Ephesians 6:11-17), but it is wanting, the weight of faith residing with the Nonconformists. Again, self-reference is there, since Marvell is an M.P., and by representing Turner as a divided Parliament, he voices his own doubts about the rectitude of the representative within which he sits. Another double-take, and one that personally reflects in another way: Marvell describes Croft's attempt to hold his book back from distribution in order to wait for the return of Parliament, which had been prorogued just as it was originally ready. These are just like the tactics used by Marvell himself in the 1660s when attacking Clarendon's ministry. ${ }^{35}$ One more switch is the direct and compassionate tone in which Marvell's speaker completes this section. That tone completes a sense in the prose that we would much rather be in Marvell's head than in that of his opponents. 
In all of this, the energetic deployment of surprisingly unusual, decontextualised, indecorous, words marks the presence of a poet. In Mr. Smirke, printed dispute is represented as a fist fight with words that embody the physical - for instance, in the game of "Hot-cockles," and also where "expose" and "extended" are redefined to mean "execute" (in that it suggests a flaying). Animadversion is likened to throwing eggs at those in the pillory or stocks, and underwritten by a further list of kinetic vocabulary: "galls," "hank," "Dint," "Culls," "Tiring" (a hawking word), "snush" (meaning the enforced taking of snuff), in addition to vivid portrayals of compelled communion and baptism in the Church of England as force-feeding and drowning. In The Rehearsal Transpros'd, the equivalent terms are often taken from Parker himself, while in Remarks upon a Late Disingenuous Discourse, exaggeratedly silly formal terms ("Theologants" for theologians - the only such usage recorded in $O E D$ ) compete with the highly animated: divines writing sermons are said to "palm up" higher, as if they were labouring men.

Marvell's targets are abusers of words. Turner is responsible for nonsense: "that" and "what" become the same things inside one sentence, so that Turner is a "killer" in words. This reads almost as Marvell commenting on his own or other witty poetry: the risk is that wit will produce killing words, and no joke, since killing words connect with religious persecution. Turner is so unscriptural in representing God's communication with Abraham that masque machinery will do a better job, says Marvell, and this looks suspiciously like the conjunction of masque and scripture words to describe the meadows in "Upon Appleton House," stanza 49. While it becomes necessary to use a Buckingham or Rochester quotation to ridicule Parker, making a connection with Marvell's use of the bawdy and the erotic in his own verse, it is also necessary to reverse Parker as well as "transprose" Bayes in order to expose the abuses in their words: hence "disintricated" and "disoccidented."

The Rehearsal Transpros' $d$ begins with a patina of literary allusion that looks like a poetic autobiography of Marvell, even as his prose develops. Thus, the weaknesses of nature are expressed through the Italian (and an English translation) of Amaryllis in Guarini's Il Pastor Fido. In this world, Bishop Parker becomes a whining nymph, complaining. At the end of this section Bayes (or is it Bramhall?) is likened to an old-fashioned romance hero (albeit writing with the complicated style of the mid-seventeenth-century French romances), and one whose fitting poetry parodies that given by Marvell to Cromwell in "An Horatian Ode." Indeed, Aubrey noted that Marvell quoted a now lost poem by Ogilby entitled the "Character of a Trooper." 36 Marvell's Parker looks at a bloated reflection of himself in a 
mirror - not unlike "Damon the Mower""s version of the Polyphemous eclogue in Thucydides - and, like Damon, he is discomforted by the dog days of high summer. ${ }^{37}$ More famously, the conceit in "A Dialogue between the Soul and Body" of the soul as the torturing rack of the body, so that, stretched and upright, he imagines himself as a walking precipice, always in danger of falling over himself, is reworked to suggest the exaggerated heights of Parker's delusion: "he was stretch'd to such an height in his own fancy, that he could not look down from top to toe but his Eyes dazled at the Precipice of his Stature." 38 Part of the trace of Hobbes in The Rehearsal Transpros' $d$ is the critique of romance, signaled as well by the approving references to Samuel Butler's mock romance-epic Hudibras (1663, 1664, 1678), despite Butler's own severe treatment of the Puritans. ${ }^{39}$ More understandable is the invocation of the Platonic love cult of the Renaissance, instanced on the conjunction of astronomy and astrology in "The Definition of Love," now redirected in The Rehearsal Transpros'd to mock Parker's desire for absolute authority. "As smiling and frowning are performed in the face with the same muscles very little altered; so the changing of a line or Two in Mr. Bayes at any time, will make the same thing serve for a Panegyrick or a Phillippick," wrote Marvell of Parker, but the sentence applies equally to himself in respect of method. ${ }^{40}$ The Rehearsal Transpros'd, Part 1, consists of an exhaustive literary map, before Parker's association of Marvell with Milton prompted the famous evaluation of Milton and Areopagitica in The Rehearsal Transpros'd, Part 2.

Finally, showing that this writer's sarcasm and irony can pass experts by, there is the famous passage towards the end of The Rehearsal Transpros' $d$, Part 1, in which the speaker explains the causes of the Civil War but notes that "it was a cause too good to have been fought for." This has been taken as a private statement of a moderate's regret for any political, religious or social conflict. But, as Jennifer Chibnall shows, the phrase taken from "To his Coy Mistress" and reversed, "the world will not go the faster for our driving," means, in pamphleteering terms, the precise opposite of what it appears to be saying (and more like the sense of the poem): the King should be bringing the terms of toleration to completion as quickly as he can. ${ }^{41}$ And at the same time, the description of the causes of the Civil War itself looks notably unbelievable. The author (part-controversialist, part carpe diem lover) is looking at us with a big grin on his face.

It may be that the rise of history as a mode of exposition in Marvell's prose works introduced that removed or invisible authorial perspective that would be so necessary in Remarks upon a Late Disingenuous Discourse. The recourse to Suetonius in The Rehearsal Transpros'd as a reference text for the discovery of tyranny grows to the extensive weaving together of church 
history in A Short History. Even here, Marvell cannot resist the parallel move: surely Herbert Croft is a Jovianus in Salisbury, and to "expose" him opens the door to Arianism, as well as episcopal tyranny, and this was exactly what had happened in the Restoration, with several powerful bishops, Sheldon even, scarcely masking their anti-Trinitarian views. ${ }^{42}$ By the time of An Account of the Growth of Popery and Arbitrary Government, Marvell found his rhythm for extraordinarily astute, to the moment, political analysis, rendered in terse prose that raises persuasiveness and excitement in equal proportions. Here Marvell continued the mode of representing Parliamentary procedure that had begun in The Last Instructions to a Painter. Indeed, since so much of his correspondence is commissioned newsletters or virtual versions thereof, it is hard to see how this mode of political journalism did not come easily to him.

In all of this, it is crucial that there be a space for free and speculative play, especially if you resist, as Marvell did in Remarks upon a Late Disingenuous Discourse, hard predestination theology. Freed from the claims of political allegory in "Upon Appleton House," and before the panegyric of Mary Fairfax begins, the poet speaker enters a state of mental bliss, in which he becomes the hermetic magus enjoying intercourse with plants, then playfully imagines himself as a bishop of the grove (earlier the poem displays undisguised hostility to the Archbishop of York), before ultimately hiding in the willows, the trees being symbols of public weakness. The apparent echoes of druidic priesthood, and the Anglican associations of fishing, are overborne by the description of the River Wharfe as a second Nile, and just before that, of a crucified speaker or one who is chained so he will drown as the tide rises. The forms that religious teaching takes are not to be dismissed (as does Milton when he scarcely mentions the crucifixion in his mature poetry) but acknowledged as an endlessly fruitful resource for speculation - until your next duty makes a demand on you. A similar reading could be produced for that other poem of solitariness, "The Garden."

Such must have been the reading experience of the Miscellaneous Poems when they appeared in 1681 during the Exclusion Crisis. If you had been lucky enough to acquire an uncancelled copy, you would have been able to read the astonishing Cromwell poems alongside what I have presented as a consistent interrogation of the forms, identities and values by which religious truth is known, even as poetry is Puritanized, and Puritanism is aestheticized. And informed readers would have come to the volume after the publication of all the prose works, by turns hilarious and subversive, of enormous verbal energy, and always dedicated to the sovereignty of conscience and both religious and political liberty. The question that follows is how to interpret the collection with the order of the verse as it is published. ${ }^{43}$ 
In an illuminating and memorably witty essay on Marvell's religion, William Lamont implores us to search for the "bloody horse" of Marvell's religion, as opposed to the "snaffle and curb" for which the poet will always be primarily read. ${ }^{44}$ My point is that the "bloody horse" is as much in the "snaffle and curb" as anywhere else. "Wit in a roundhead" is an apt phrase to describe Marvell's sometime associate, the journalist and sometime republican Marchamont Nedham. But by the late 1670s, much to Marvell's disgust, Nedham was writing in the pay of Roger L'Estrange, Charles II's censor. Nedham could not keep principles (although even that position might be challenged), but Marvell could. And if "Wit in a roundhead" is not right, "wit in a Puritan" certainly is, or better still, "The Laughing Puritan." There is a lost portrait of Marvell by Sir Peter Lely, but it would have been more appropriate had Franz Hals been the painter. Perhaps with the smiling poet looking somewhat like a mower, and with a hint of the iconography of death in the background. That would be a rhyme in painting.

\section{Notes}

1. Major editions appearing at that time were The Poems and Letters of Andrew Marvell, ed. H. M. Margoliouth, 3rd ed. rev. by Pierre Legouis with the collaboration of E. E. Duncan-Jones (Oxford: Clarendon Press, 1971); The Complete English Poems, ed. Elizabeth Story Donno (New York: St. Martin's Press, 1974); and The Rehearsal Transpros'd, and The Rehearsal Transpros'd, the Second Part, ed. D. I. B. Smith (Oxford: Clarendon Press, 1971).

2. See John M. Wallace, Destiny his Choice: The Loyalism of Andrew Marvell (London: Cambridge University Press, 1968).

3. As argued in Warren L. Chernaik, The Poet's Time: Politics and Religion in the Work of Andrew Marvell (Cambridge: Cambridge University Press, 1983), p. 7.

4. John Creaser, "'As one scap't strangely from Captivity': Marvell and Existential Liberty," in Marvell and Liberty, ed. Warren Chernaik and Martin Dzelzainis (Houndmills, Basingstoke, Hampshire: Macmillan; New York: St. Martin's, 1999), pp. 145-72. See also John Creaser, "Prosody and Liberty in Milton and Marvell," in Milton and the Terms of Liberty, ed. Graham Parry and Joad Raymond (Woodridge: D. S. Brewer, 2002), pp. 37-55.

5. Ramie Targoff, Common Prayer: The Language of Public Devotion in Early Modern England (Chicago: University of Chicago Press, 2001).

6. See J. C. Davis, "Religion and the Struggle for Freedom in the English Revolution," Historical Journal 35 (1992): 507-30.

7. See the relevant apparatus in Andrew Marvell, Poems, ed. Nigel Smith (London: Pearson Longman, 2003); this edition will be used for citations. See also C. B. Hardman, "Row Well Ye Mariners," Review of English Studies 51 (2000): 80-82.

8. The clergyman who officiated at the wedding, Dr. John Hewitt, an Anglican, was shortly to be associated with a plot against Cromwell, incriminated and executed. 
154 / Renaissance and Reformation / Renaissance et Réforme

9. On Puritans and poetry, see further Nigel Smith, Literature and Revolution in England, 1640-1660 (New Haven, CT: Yale University Press, 1994), ch. 8, and Sharon Achinstein, Literature and Dissent in Milton's England (Cambridge: Cambridge University Press, 2003), ch. 8.

10. See James Loxley, "Prepar'd at Last to Strike in with the Tyde? Andrew Marvell and Royalist Verse," The Seventeenth Century 10 (1995): 39-62.

11. These were, respectively, Henry Hawkins, Maciej Kazimierz Sarbiewski, and Luis de Gongora.

12. See the notes in Smith, ed., p. 226, and Brian Patton, "Preserving Property: History, Genealogy, and Inheritance in 'Upon Appleton House," Renaissance Quarterly 49 (1996): 824-39.

13. See John Carey, "Reversals Transposed: An Aspect of Marvell's Imagination," and Christopher Ricks, "Its Own Resemblance," in Approaches to Marvell: The York Tercentenary Lectures, ed. C. A. Patrides (London: Routledge and Kegan Paul, 1978); also David Reid, “The Reflexive Turn in Early Seventeenth-Century Poetry,” English Literary Renaissance 32 (2002): 408-25. The "boomerang" remark was made by John Carey in "Ensnared with Flowers," BBC Radio 3 Broadcast, 19 August 2003, 8:10 p.m. BST.

14. John Milton, Areopagitica, Complete Works of John Milton, ed. Don Wolfe et al., 8 vols. (New Haven, CT: Yale University Press, 1953-82), 2: 555.

15. Paul Mathole, "Marvell's Martyrs," in Early Modern Perspectives on Martyrs and Martyrdom, ed. Paul Scott (Leiden: Brill, forthcoming).

16. Nigel Smith, "Martyrs, Terrorists, Poets," Churchill Lecture, University of Bristol, 28 January 2003.

17. See further, a Short History, which ends with three persecution and torture images, and thereby connects with the well-known reference to torture in "The Gallery," st. 2. Roman Catholics succumb to the "Terrours of the phansy" and are "Tenants for their Souls" in An Account of the Growth of Popery and Arbitrary Government (1677), p. 7, while later in the tract the execution (and damnation) of the nation is imagined (p. 15).

18. Creaser, “As one scap't strangely from Captivity," pp. 157-58.

19. The resemblance is no surprise, given Swift's devotion to Marvell. See Jonathan Swift, A Tale of a Tub, ed. A. C. Guthkelch and D. Nichol Smith (Oxford: Clarendon Press, 1958), pp. 9-10, and Raymond A. Anselment, "Betwixt jest and earnest": Marprelate, Milton, Marvell, Swift and the Decorum of Religious Ridicule (Toronto: University of Toronto Press, 1979), pp. 125 ff.

20. See Livy, History, 45.10; Polybius, Histories, 29.27.

21. Journal of the House of Commons, 55 vols. (1803), 7: 389; Guy de Miège, A Relation of Three Embassies (1669).

22. Preface to Religio Laici (1682), in John Dryden, The Poems of John Dryden, ed. Paul Hammond, vol. 2 (London: Longman, 1995), p. 102.

23. Mr. Smirke, pp. 6-7.

24. Ibid., p. 4.

25. See Christopher Martin, "Flecknoe's Cabinet and Marvell's Cankered Muse By," Essays in Criticism 40 (1990): 54-66, and Nigel Smith, "'Courtesie is fatal': The Civil 
Nigel Smith / The Boomerang Theology of Andrew Marvell / 155

and Visionary Poetics of Andrew Marvell," Chatterton Lecture on Poetry 1998, Proceedings of the British Academy 101 (1999): 173-89.

26. The Rehearsal Transpros'd, Part 1, The Prose Works of Andrew Marvell, ed. Annabel Patterson et al., 2 vols. (New Haven, CT: Yale University Press, forthcoming [2004]), 1: 63.

27. Mr. Smirke, p. 5.

28. Raymond A. Anselment, "'Betwixt Jest and Earnest': Ironic reversal in Andrew Marvell's The Rehearsal Transpros'd," Modern Language Review 66 (1971): 284.

29. Mr. Smirke, p. 6.

30. Ibid., p. 6.

31. See Smith, "'Courtesie is fatal.",

32. Mr. Smirke, 8; Ovid, Metamorphoses, 2.631-32.

33. George Etherege, The Man of Mode, in Restoration and Eighteenth Century Comedy, ed. Scott McMillan, 2nd ed. (New York: Norton, 1997), p. 167, 11. 17-18. The play was first performed in March 1676.

34. See also the self-confessed use of allegory in the opening section of Remarks upon a Late Disingenuous Discourse (1678), p. 3, comparing ministers to Adam, labouring in Eden.

35. See Smith, ed., pp. 321-26.

36. Identified by Martin Dzelzainis from an annotation by John Aubrey; see Patterson et al., eds., 1: 54, n. 87.

37. The Rehearsal Transpros'd, Part 1, in Patterson et al., eds., 1: 49-50.

38. Ibid., 1: 75 .

39. See Jon Parkin, "Liberty Transpros'd: Andrew Marvell and Samuel Parker," in Chernaik and Dzelzainis, eds., pp. 269-89.

40. The Rehearsal Transpros'd, Part 1, in Patterson et al., eds., 1: 69.

41. Jennifer Chibnall, "Something to the Purpose: Marvell's Rhetorical Strategy in The Rehearsal Transpros'd (1672)," Prose Studies 9 (1986): 80-104.

42. See Smith, ed., p. 406, n. 167.

43. See Annabel Patterson, "Miscellaneous Marvell?", in The Political Identity of Andrew Marvell, ed. Conal Condren and A. D. Cousins (Aldershot: Scolar Press 1990), pp. 188-212.

44. William Lamont, "The Religion of Andrew Marvell: Locating the 'Bloody Horse,"' in Condren and Cousins, eds., pp. 135-56. 